\title{
Securitising Covid-19? The Politics of Global Health and the Limits of the Copenhagen School
}

\author{
Daniel Edler Duarte* \\ Marcelo M. Valença*
}

\begin{abstract}
The COVID-19 pandemic has sparked controversies over health security strategies adopted in different countries. The urge to curb the spread of the virus has supported policies to restrict mobility and to build up state surveillance, which might induce authoritarian forms of government. In this context, the Copenhagen School has offered an analytical repertoire that informs many analyses in the fields of critical security studies and global health. Accordingly, the securitisation of COVID-19 might be necessary to deal with the crisis, but it risks unfolding discriminatory practices and undemocratic regimes, with potentially enduring effects. In this article, we look into controversies over pandemic-control strategies to discuss the political and analytical limitations of securitisation theory. On the one hand, we demonstrate that the focus on moments of rupture and exception conceals security practices that unfold in ongoing institutional disputes and over the construction of legitimate knowledge about public health. On the other hand, we point out that securitisation theory hinders a genealogy of modern apparatuses of control and neglects violent forms of government which are manifested not in major disruptive acts, but in the everyday dynamics of unequal societies. We conclude by suggesting that an analysis of the bureaucratic disputes and scientific controversies that constitute health security knowledges and practices enables critical approaches to engage with the multiple - and, at times, mundane - processes in which (in)security is produced, circulated, and contested.
\end{abstract}

Keywords: securitisation; Copenhagen School; everyday politics; health security; international political sociology; critical security studies; Covid-19 pandemic.

\section{Introduction}

The social and economic crises caused by the COVID-19 pandemic have posed extraordinary challenges for governments and societies. Since vaccines and effective prophylactics

\footnotetext{
* University of São Paulo, São Paulo-SP, Brazil; edlerduarte@gmail.com. ORCID iD 0000-0002-0138-2982.

** Brazilian Naval War College, Rio de Janeiro-RJ, Brazil; marcelo.valenca@marinha.mil.br. ORCID iD 00000002-4930-9805.
} 
were not initially available, most epidemiologists and policymakers have agreed on the need for non-pharmaceutical interventions (including quarantine regulations), unprecedented investments in hospital resources, and virus-tracing capabilities to identify clusters of infections and contain outbreaks.

In this context, the pandemic motivated emergency security responses. Both UN Secretary-General António Guterres and World Health Organization (WHO) Director-General Tedros Adhanom emphasised the need for exceptional measures to tackle the virus. According to Guterres (2020), 'the world faces its gravest test' since the founding of the UN, which 'poses a significant threat to the maintenance of international peace and security.' Therefore, political leaders should gather resources for the 'fight of a generation.' Adhanom also used war metaphors to depict the magnitude of the challenge, as he noted that public authorities were experiencing 'an unprecedented threat, but it's also an unprecedented opportunity to come together as one against a common enemy - an enemy against humanity' (Adhanom 2020). Health professionals and scientists furthered securitised discourses. The Imperial College COVID-19 Response Team, for example, reported that the global impact of the coronavirus 'has been profound, and the public health threat it represents is the most serious seen in a respiratory virus since the $1918 \mathrm{H} 1 \mathrm{~N} 1$ influenza pandemic' (Ferguson et al 2020: 1).

The concept of health security gained prominence with the global HIV/AIDS pandemic in the 1990s, but scholarly interest has steadily grown, especially during outbreaks of highly infectious diseases (Curley 2011; McInnes and Rushton 2013; Benton 2017; Wenham and Farias 2019). In the case of Sars-Cov-2, analysts have emphasised the political dilemmas of introducing lockdowns and biometric surveillance to control the virus (Morozov 2020; Goldenfein, Green and Viljoen 2020). Despite the need for emergency policies, critics fear that the health crisis will be used by neoliberal governments to roll out unpopular economic reforms and to assemble security apparatuses to the prejudice of democracy and individual liberties (Agamben 2020; Klein 2020; Harvey 2020). In this context, securitisation theory and what is known as the Copenhagen School have offered a remarkably popular analytical framework (Al-Sharafat 2020; Baele 2020; Ibrahim 2020; Eves and Thedham 2020; Krasna 2020; Mukherjee 2020; Nunes 2020; Sears 2020; Stivas and Smith, 2020; Stivas and Sliwinski 2020; Pfrimer and Barbosa Jr. 2020).

In essence, securitisation is the process by which 'normal' items on the political agenda come to be treated as urgent existential threats. Securitised issues are prioritised in decision-making processes, warrant exceptional measures, and enable security apparatuses to be deployed to ensure extraordinary responses to whatever challenge arises (Buzan, Wæver and de Wilde 1998). Classifying a given phenomenon as a security issue is thus not a neutral description of reality, but an intersubjective construction biased towards the militarisation of politics, which reduces the repertoire of action and elevates the urgency of certain agendas. Given the risks inherent in breaking with the 'normal political rules of the game' (Buzan, Wæver and de Wilde 1998: 24), part of the global health field has indicated a need for de-securitisation processes (McInnes and Lee 2006; Elbe 2010a), for 
systems of institutional checks and balances to be strengthened, and for investment to be ensured in health policies that go beyond times of crisis.

This article, however, is not another application of the securitisation framework to investigate states' responses to COVID-19. Instead of evaluating political leaders' discourses so as to decide whether or not a securitisation process was in place, it discusses how securitisation theory has been taken up in the field of global health and how it is shaping the health security literature. Specifically, it points up the Copenhagen School's limitations as a source for critical approaches to global health and, for that purpose, raises an empirical-methodological issue and investigates an ethical-political problem.

It is tempting, on the one hand, to apply the analytical framework of the Copenhagen School to analyse the various issues addressed by security logic and imminent threat discourse. However, choosing to focus on emergency decisions and acute disruptions of political activity betrays a conservative reading of politics and conceals the abundant political life and ephemeral politics' ongoing in everyday power relations and the daily practice of security professionals (Guillaume and Huysmans 2019: 282; Amoore and de Goede 2008; Huysmans 2011). In that respect, this article will show how the health-security nexus is constructed out of multiple institutional disputes, including an accumulation and (re)appropriation of legitimate knowledge about the disease, techno-political tools for measuring contagion, and the formation of transnational networks that connect the security and health fields.

Conversely, while critical approaches have alerted to the risks of warlike rhetoric in the fight against COVID-19 (Caso 2020; Caetano 2020), this article goes further, to argue that the critical aspirations of securitisation theory are anchored in a conservative, ahistorical conception of politics (Huysmans 2006; Stritzel 2011). The single-minded focus on the politics of elites hinders a genealogy of modern control apparatuses and their construction out of medical and security knowledge (Foucault [1974]2019). Securitisation theory thus neglects violent forms of government which are manifest not in major disruptive acts, but in the everyday practices of unequal societies. In short, the discussion here addresses not only the 'securitisation dilemma' (Olesker 2018), which arises when actions taken to quell threats ultimately heighten the risks to referent objects, but also the making of the health-security nexus, so as to highlight the Copenhagen School's limitations with regard to critical analysis.

In order to better develop the argument, the article is divided into three parts in addition to this introduction. Firstly, securitisation theory is presented. We address the Copenhagen School's approach to analyse the construction of the health-security nexus and the responses to COVID-19. The second part discusses the limitations of securitisation as an analytical framework and proposes that critical approaches to the pandemic should avoid the binary interpretations of politics as a choice between norm and exception, and opt rather to address 'banal, everyday security practices. The final section explores the opportunities that other critical approaches to (in)security provide in terms of enabling a more plural analytical agenda of global health policies. 


\section{The Copenhagen School and the Security Studies Agenda}

Securitisation theory gained traction in the 1990s as an alternative to the polarisation then prevalent in security studies between realist orthodoxy and its critics. On the one hand, realists claimed the focus should remain on 'policies that states adopt in order to prepare for, prevent, or engage in war' (Walt 1991: 212). According to this perspective, inroads by new topics and actors polluted the field of security studies and jeopardised its conceptual coherence. On the other hand, critics were interested in a broad set of events that impaired people's quality of life and constrained political freedom (Ullman 1983). Economic crisis, climate change and transnational crime, for example, were serious challenges not to be effaced from political agendas. The end of the Cold War was to dilute the obsession with nuclear weapons and military budgets, making space for the analysis of other dynamics of insecurity, such as structural poverty, arms trafficking and the 'war on drugs.' Therefore, security was conceived both as the absence of threats and a tool of emancipation, 'freeing [people] from those physical and human constraints which stop them carrying out what they would freely choose to do' (Booth 1991: 319).

Instead of dwelling further on debates about the ontology of security, Buzan, Wæver and de Wilde (1998) proposed an analytical framework that captured the social construction of security threats and the politics of security agenda setting. Securitisation is not a description of realities and is not about assessing the materiality of threats: it is a self-referential definition. A phenomenon becomes a threat in the act of enunciating it as such or, as noted by Wæver (2011: 472), 'the security quality does not belong to the threat but to its management.' Nonetheless, this is not a discourse where 'anything goes': the meaning of security is constructed in an intersubjective process, that is, one requiring a shared understanding of its underlying logics and meanings. Specifically, the securitisation process produces a political performance from a speech act comprising two movements: the linguistic construction of insecurity and its acceptance by the audience. The fact that individuals or groups talk about security does not make an issue a security matter: '[w] hat is essential is the designation of an existential threat requiring emergency action or special measures and the acceptance of that designation by a significant audience' (Buzan, Wæver and de Wilde 1998: 27). Thus, security research does not come down to discourse analysis; it is necessary to understand how the audience reacts and whether or not it legitimises exceptional measures and military mobilisation.

The securitisation process occurs when a securitising actor is successful in advancing the rhetoric of an existential threat, thus elevating an issue of 'normal' politics to emergency status requiring extraordinary measures. Securitisation thus constitutes:

[A] more extreme version of politicization. In theory, any public issue can be located on the spectrum ranging from nonpoliticized (meaning the state does not deal with it and it is not in any other way made an issue of public debate and decision) through politicized (meaning the issue is part of public policy, requiring government decision and resource allocation or, more rarely, some other form 
of communal governance) to securitized (meaning the issue is presented as an existential threat, requiring emergency measures and justifying actions outside the normal bounds of political procedure). (Buzan, Wæver and de Wilde 1998: 23-24)

To speak of security is thus to introduce a structure of meanings and conventions that sanctions certain practices and redirects institutional arrangements, social relations, and policies on a rationality of its own. Its distinguishing feature is a specific structure, which enables security actors and phenomena to be identified in sectors other than the military and political. In summary, from the standpoint of securitisation theory, 'security knowledge is no longer defined by the nature of events and developments that one researches [...] but by a skill to unravel processes in which this particular rationality is set at work' (Huysmans 2006: 27). The grammar of security proposed by the Copenhagen School introduces epistemological premises that not only reorient research agendas (how to study security) and expand their scope (multi-sector analysis), but they transform the field's very identity. Huysmans (2006: 27) argues that the logic of securitisation poses a challenge to the production of legitimate knowledge in security studies: security experts are no longer 'people who are proficient in studying [the] military [...] but professionals who are skilled in understanding political inscriptions of particular security rationalities.'

\section{Securitisation and the Health-Security Nexus}

Since the 2000s, when the UN Security Council declared the HIV/AIDS pandemic a threat to peacekeeping operations in sub-Saharan Africa (UNSC, 1208/2000), many authors have applied securitisation theory to analysing global health and security agendas (Rushton and Youde 2015). Elbe and Buckland-Merrett (2019: 132) recalled that the accelerating process of globalisation had brought the risks of pathogen spread to an important point of inflection, permanently adding them to national security agendas, which 'gradually became much more preoccupied with biological threats and dangers linked to new forms of epidemiological connectivity and interdependence brought about by the rapid movement of goods, people, and livestock across international borders.'

Diseases cross frontiers and can pose risks requiring urgent coordinated responses, whose referent objects are national sovereignty, human security, global public health, and biosecurity (McInnes 2015). The specification of what needs to be protected depends on the securitising agent and may vary in different contexts, but it is common for health crises to raise concerns about the global economy, the operational capability of armed forces and the aggravation of local vulnerabilities, which can trigger political instability and migratory flows. The WHO (2007) works with an even broader definition of health security, which includes new infectious diseases for which there are as yet no medicines or containment protocols, as well as diseases that weaken the food production chain, leading to shortages and hunger, and environmental catastrophes.

Securitisation theory has been used to help understand the health-security nexus on a variety of fronts. There are critical analyses of emergency preparedness (Katz and Sorrell 
2015), of the WHO's role as norm entrepreneur and securitising actor (Hanrieder and Kreuder-Sonnen 2014), of the impact of securitisation processes on public investments in the health sector (Stevenson and Moran 2015) and of the risks of militarised responses to health crises (Watterson and Kamradt-Scott 2016). The Copenhagen School also energised debates on the banalisation of authoritarian health policies (Wenham 2019), the stigmatisation of infected populations (DeLaet 2015), the impact of contagious diseases on armed conflicts (McInnes 2009), and on bioterrorism and racism (D’Arcangelis 2017) ${ }^{1}$.

Securitisation processes have thus become a common theme in the global health literature, especially during major outbreaks, including HIV/AIDS (Elbe 2006), SARS (Kamradt-Scott 2015), H5N1/bird flu (Curley 2011), Ebola (Benton 2017) and Zika (Wenham and Farias 2019). It is thus no surprise that the vocabulary of the Copenhagen School is now employed to describe the challenges posed by COVID-19 and the control measures applied around the world (Al-Sharafat 2020; Baele 2020; Ibrahim 2020; Eves and Thedham 2020; Krasna 2020; Mukherjee 2020; Nunes 2020; Sears 2020; Stivas and Smith 2020; Stivas and Sliwinski 2020; Pfrimer and Barbosa Jr. 2020).

Candidates for the role of securitising actor abound. Besides Guterres and Adhanom, many heads of states have described the virus as an existential threat. Donald Trump, for instance, claimed the US was suffering the worst attack in its history: ' $t$ ]his is worse than Pearl Harbor, this is worse than the World Trade Center. There's never been an attack like this' (BBC 2020). Researchers have also collected declarations by French President Emmanuel Macron that France was 'at war with the coronavirus' (Erlanger 2020); by former Italian Prime Minister Giuseppe Conte calling for Italians to stay at home while the country underwent its 'biggest test since the Second World War' (Lowen 2020); by South Korean President Moon Jae-in on the need for South Korea to 'wage a war' against Covid-19 (Kuo 2020); and Xi Jinping summoning Chinese citizens to a 'decisive battle' in the 'people's war' against the pandemic (Tian 2020). The list could go on.

Echoing recent debates in the literature, many researchers have warned of the need to de-securitise medical practice and discourse, while acknowledging the value of permanent investments in public health systems (Elbe 2010a; Elbe 2011). After all, as noted by Buzan, Wæver and de Wilde (1998: 35), security is not 'a good to be spread to ever more sectors.' On the contrary, as far as global health challenges are concerned, security for some generally means insecurity for others. Securitisation processes induce a 'garrison mentality' in public authorities which not only discriminates and stigmatises potential carriers of the disease, but also justifies violent practices to control contagion, including detentions, forced vaccinations and mandatory physical inspections (McInnes and Lee 2006: 9). Authors have warned that the purported securitisation of the COVID-19 pandemic has sparked disputes over medicine and protective equipment, prejudicing developing countries and worsening global inequalities (Kamdar 2020; Chadwick 2020; Bradley 2020). Wehnam (2019) reports that encroachment by military and intelligence agents into collective health issues worsens at times of crisis, and security performances in the health field themselves become the major threats. On this view, society as a whole and global health researchers in particular - should 'critically examine how public health 
crises are unnecessarily framed through the rhetoric of war to serve militaristic agendas' (Pfrimer and Barbosa Jr. 2020: 140).

While securitisation processes do pose risks, some argue that they also offer benefits. Elbe (2006), for example, notes that securitisation of the HIV/AIDS epidemic helped mobilise public opinion in favour of breaking patents on medicines that were fundamental to patients' quality of life. In other words, effective methods of treating the disease became public policy only because governments were able, in view of a public health threat, to impose exceptional measures on the pharmaceutical industry and existing intellectual property rules. Successful securitisation processes may also prevent health emergencies of international concern from being neglected and treated as low-risk seasonal diseases (Honigsbaum 2017).

Nunes (2020) has suggested that a similar process may occur with COVID-19, thus favouring expansion of public health service care capacity and emergency investments in research into vaccines and other treatments. He goes further to argue that critical studies of security and global health are lacking a normative proposal tied directly to a praxis committed to social change. The inclusion of public health on the security agenda may trigger draconian practices of government, but also 'the removal (or at least alleviation) of constraints upon the lives of individuals and groups' (Nunes 2014: 8). Specifically, the formation of the health-security nexus may promote 'mechanisms that can adequately address health inequalities, vulnerabilities and harm' (Nunes 2014: 10).

In Brazil, initial analyses of responses to the new coronavirus explored that controversy. Researchers discussed the need to strike a balance between protective measures, including policies of exception that facilitate the deployment of operating and financial resources, and individual liberties and human rights. While, on the one hand, Covid-19 has taken a devastating toll of vulnerable populations, on the other, securitisation can ignite disputes for medical equipment, conceal inequalities in public health services, militarise social distancing regulations, expand and entrench surveillance mechanisms, and justify violent police repression (Nunes 2020; Ventura et al. 2020a, 2020b; Wermuth and Morais 2020; Reis 2020; Corrêa Filho 2020; Pfrimer and Barbosa Jr. 2020).

In this regard, the securitisation process can be seen as a rhetorical strategy to draw attention to a given issue and direct public opinion to the need for urgent action. However, that is dangerous use of language. As Elbe (2011:220) has warned, health professionals face the dilemma of when and how to 'play the global health security card.' These controversies engender an ambiguous normative position towards the health-security nexus: securitising limits the political debate, marginalises or even excludes those with alternative views, and restricts freedom [...] [but] justice claims work best if they are supported by security claims' (Diez 2020). As summarised by Ventura (2016: 3):

$[V]$ iewing the response to international emergencies only through the limited prism of security would condemn global health to an infinite succession of periods of 'war' interspersed with 'truces' focused on surveillance systems, rather than confronting the causes of the epidemics, rooted in the social determinants of health. If the 
immediate responses are not accompanied by structural changes capable of promoting a radical reduction in inequalities, the question remains: who will truly be safe at the end of each 'war'?

The next section will continue to explore this controversy, but from a different perspective. Instead of balancing the opportunities and risks intrinsic to the interrelation between security and health, it will examine the analytical and political limitations of the Copenhagen School, arguing that securitisation does not hold emancipatory potential, and that by working on a political logic circumscribed by rupture and exception, it ends up reinforcing a conservative approach to politics.

\section{The Limitations of Securitisation Theory in Critical Approaches to Health Security}

Over the past twenty years, many authors have criticised the initial formulations of the Copenhagen School and discussed their epistemological flaws. Efforts to amend securitisation theory have included not only new formulations of the role of audience and the characterisation of securitising actors (Balzacq 2005; Léonard and Kaunert 2011), but also debates about the centrality of discourses and the lack of thinking about materiality, visual representations and bodily performances (Vuori 2008; Aradau 2010; Guillaume 2018), and attempts to bring sociological perspectives (drawing mainly on Bourdieu) to bear on securitisation processes (Bigo 2002; Leander 2011). The Copenhagen School has also been criticised for its inapplicability beyond Western democracies (Wilkinson 2007; Bilgin 2010), the absence of debates on gender and post-colonialism (Hansen 2000; Moffette and Vadasaria 2016), and for its 'universal' and conservative aspects (Stritzel 2011). In this sense, a growing number of critical security scholars have agreed that the framework proposed by Buzan, Wæver and de Wilde (1998) 'seems to have become more of an impediment to critical research than useful equipment, [...] [since] securitisation hides more than it helps us see' (Aradau 2018: 300).

This section will argue specifically that analysis of moments of rupture and policies of exception conceal the historical constitution of government apparatuses that are reproduced in ordinary data collection, statistical production, demographic mapping, risk analysis and so on (Bigo 2002; Huysmans 2006, 2011; Howell 2014). As a result, this approach ignores routine forms of social control resting on medical practice and knowledge, thus neglecting the ability of expert professionals (and their scientific knowledge) to impact the field with their intellectual capital and to legitimise certain security practices over others.

\section{Securitisation, Everyday Practices, and 'Little Security Nothings'}

The Copenhagen School is not alien to techno-scientific debates and their influence in shaping meanings of security. As Buzan, Wæver and de Wilde (1998: 72) have argued, specialised knowledge - in this case epidemiological discourse - may support 'authoritative assessment of threat for securitizing or de-securitizing moves.' The argument set out in 
this section is different, however. While the Copenhagen School considers science to be an auxiliary discourse in the epistemological construction of existential threats (specialists are 'functional actors' who authorise speech acts), it is argued here that scientific/medical and security practices and knowledge are interwoven in the everyday. The grammar proposed by Buzan and Wæver disregards the multiple ways in which the security rationality insinuates itself into the various dimensions of society, but also how it is reshaped and, as noted by Elbe (2011; Elbe and Buckland-Merrett 2019), instrumentalised by medical knowledge. In other words, securitisation theory excludes:

[A]ll the instances where actors may mobilise the term 'security' in ways that do not readily conform to this particular grammar, but which may still be politically significant $[\ldots]$ or all those little security 'nothings' that do not pass the threshold of the formal speech act grammar but are nevertheless highly significant politically. (Elbe and Buckland-Merrett 2019: 137)

Bigo (2002), considering alternatives to the Copenhagen School, argued that securitisation processes build on legitimacy gains by security professionals in political domains foreign to their discourses and practices. Accordingly, instead of analysing linguistic performance by actors of the political elites, Bigo advocated studying the bureaucratic strategies employed in accumulating information, resources and expertise which make security professionals key actors in discussions of issues as diverse as immigration, poverty, and health. In those terms, 'securitization works through everyday technologies, through the effects of power that are continuous rather than exceptional, through political struggles, and especially through institutional competition within the professional security field in which the most trivial interests are at stake' (Bigo 2002: 73).

In opposition to Buzan and Wæver's formulations, Bigo claims that, a priori, there is no ontological gap between security and health policies, occasionally to be bridged by securitisation processes. The boundaries between the issues addressed by routine practices in medical laboratories, hospitals, and universities and those that call for mobilisation of military apparatuses are drawn in everyday negotiations between security and health professionals. Also, this is not a one-way street on which security knowledge colonises medical practices. As Elbe explained, controversies between these two fields result in both the securitisation of health and the medicalisation of security, because ideas about health 'reshape our understandings of security and insecurity in international relations' (Elbe 2010b: 14).

Despite COVID-19's many particularities, epidemics are recurrent events that demand emergency preparedness, information sharing, response coordination and early warning systems. The WHO and the various local health agencies have mechanisms to monitor and evaluate contagious diseases. They also designed action protocols that are adapted to the extent that initial control techniques prove successful or not (Carmo, Penna and Oliveira 2008). Definitions of 'crisis,' 'emergency' and 'pandemic' thus result from ongoing evaluation by bureaucratic institutions which employ routine risk measurement 
and assessment techniques. To speak of rupture on the basis of a discourse of securitisation is to lose sight of how these protocols for action are constructed and of the internal politics of these institutions. Decisions on the knowledge and techniques that will guide global health policies take place in institutional disputes for protagonism, in scientific controversies, and in decision-making processes under conditions of uncertainty. It is in these everyday dynamics that the legitimacy granted to security professionals authorises them to specify ways to control the virus.

Securitisation can thus be regarded as an administrative and political process embodied in practices of 'population profiling, risk assessment, statistical calculation, category creation [and] proactive preparation' (Bigo 2002: 65). Amid the crisis generated by COVID-19, discourses and public policies are modulated by indices of social isolation and algorithmic assessments of future contagion patterns. These are the devices and techniques that set the rules for action for security forces and feed into controversies over the adoption of quarantines and other social distancing measures. Variations of these devices can be found in the Brazilian cities where lockdown policies and social control measures were applied. In São Paulo, for example, collaboration between public authorities and private companies equipped local health professionals with monitoring platforms capable of measuring urban mobility. Population management during the pandemic was informed by a social isolation index and biometric surveillance devices, which identified and stopped potentially infected individuals. The government modulated the rules restricting mobility according to epidemiologists' assessments of social distancing indices, so that security measures were embedded in (and legitimated by) medical/technical knowledge (Peron et al. 2020).

Accordingly, in order to become a security issue, a new pathogen does not need to be identified as an 'existential threat' by the political elite. It is enough for it to be 'institutionally and discursively integrated in policy frameworks that emphasize policing and defence' (Huysmans 2006: 3-4). That is, the securitisation of COVID-19 is the result and not the cause of the articulation between medical and security knowledge, practices, and techniques. Thus, what is needed is for critical investigation to shift focus and dispel the judicial illusion of the political moment of decision on exceptionality and to observe the professionals who work with notions of risk, threat and uncertainty on a day-to-day basis. Ultimately, 'exceptional security practices can be understood in the context of ongoing processes of technocratic, bureaucratic and market-driven routinization and normalization' (C.A.S.E. Collective 2006: 466).

The security field is transverse, dispersed and constituted from a chain of practices and modes of classification in which it is impossible to identify a single, unique moment of decision. The speech acts stressed by the Copenhagen School are added to a complex social context, where there is an accumulation of mediations between political actors and domains, such as security and health, security and environment, and security and migration. Critical analysis should not be directed to speech acts alone, but should take in the ordinary, repetitive processes, the lesser moments and actions, that invest the security rationality in certain objects, persons and pathogens, without necessarily causing ruptures 
or changes in the social order. The question then is not just to observe processes of militarisation of daily life, but to investigate how routine activities - what Huysmans (2011) called 'little security nothings' - are engaged in producing security practices. To quote (Huysmans 2011: 376),

[s]ecuritizing develops through a wide variety of mediators that connect data, people, sites and times. [...] If mediations are numerous, constantly shifting and dispersed, it becomes very difficult if not impossible to assess which actions are actualizing a decision that brings into play the limits of a given order.

Thus, criticism of the 'jargon of exception' is not limited to denouncing manipulation of public opinion or the spreading of 'moral panic' to further unspeakable interests of local political elites (Huysmans 2008). Nor is it a matter of assessing proportionality between challenge and response, which would lead to questions as to whether social distancing measures and war budgets were appropriate to dealing with the pandemic. Although, as noted above, this is the discussion in part of the global health field (Elbe 2011; Nunes 2020; Ventura 2016), here the political implications of exception are problematised from a different perspective. This analytical framework fails to grasp not only the production of legitimate knowledge about the disease and disputes among bureaucracies in formulating appropriate responses, but also the historical constitution of government apparatuses that merge medical and security knowledge (Foucault [1974]2019; Chalhoub 1996; Elbe 2010b). The political consequences thereof are examined below.

\section{The critical limitations of Securitisation Theory}

To speak of the securitisation of global health policies presupposes an earlier point at which these two fields were separate and suggests a 'normal' health policy that is not articulated with social control measures. However, security practices and medical knowledge do share a common genealogy (Foucault [1974]2019). Accordingly, to examine sovereign decisions, performative discourses and policies of exception is to ignore the historical constitution of apparatuses of government that merge medical and security knowledge. Ultimately, this obscures the violence of everyday arrangements of social control that grow precisely out of the deep-rooted interrelations between the health/medical and security/defence fields. As Howell (2014: 976) notes,

[d] espite their apparently different spheres of operation - killing and curing - they share practitioners, resources, techniques, and language. They have not only been symbiotic in their repeated interactions with each other, they are also homologous in their strategic focus on the defence and optimisation of populations.

During the nineteenth century, public health and medical science gained space primarily in two domains. The first reflects the conditioning of mass armies, which involved 
not only treating the wounded, but also preventing the contagious diseases that decimated the ranks before they ever went into battle. The second comprises practices used to control growing urban populations. The making of a working class suited to the sort of repetitive manual tasks demanded in the factories relied on technologies of government that moulded individual conducts, inducing healthy habits (better hygiene, alcohol control, family routine) and repressing deviant behaviour. In other words, modern medicine grew out of, and overlapped with, demands from security professionals, on the one hand, to improve the performance of the armed forces and, on the other, to support police institutions in maintaining order in increasingly densely populated urban centres (Foucault [1974]2019). Thus, to separate the field of global health (as the space of normal, democratic or peaceful public policies) from health security (where militarised practices are authorised) hides the fact that 'normality' in medical practice has been historically characterised by security rationalities and militarised imaginary (Howell 2014; 2018).

This identification of the common genealogy shared by health and security has important analytical repercussions. While McInnes and Roemer-Mahler (2017), Wenham (2019) and other critical references in the global health field emphasise the problems of securitising disease control strategies in specific contexts, a historical investigation of how medical and police practices overlap may raise broader questions about the governmentalisation of political power. Elbe (2010b), for example, argues that health surveillance practices and epidemiological knowledge are not limited to hospitals and other medical institutions. On a Foucauldian approach to security, he claims that medicalisation supports the underlying rationality of government, whose aim is 'the conduct of conducts' or the power to act on the actions of others (i.e. inducing healthy habits and disease prevention policies), filtering out those who pose risks (the infected, the criminal, the abnormal) and producing social order.

In Brazil, Chalhoub (1996) showed how, already in the nineteenth century, epidemiologists' discourses and practices were central to constructing scientific legitimacy for the public administrators and private entrepreneurs who shaped urban space in local metropolises. By defining the poor classes as doubly dangerous - both criminals and propagators of diseases - medical science contributed to the emergence of modern urban management. In his studies of containment policies for the yellow fever, cholera and smallpox epidemics in imperial Brazil, Chalhoub points out that the poor classes' housing and way of life, and their relegation to peripheral areas distant from city centres were produced in an interplay of medical knowledge, private interests and police practices.

Furthermore, the lack of a historical dimension in the theorisation of Buzan and Wæver as to the constitution of security apparatuses and modern forms of government masks the role of medicine as a colonial science and its contribution to imperialist policies in the past two centuries. As described by Howell (2014: 975),

[t]he role of medicine in colonisation was not just a matter of ensuring the health of colonisers, but of working upon colonised populations, as in the military sphere, in order to shore up 'manpower.' In response to resistance, vaccination campaigns were one of the 
earliest and most extensive public health initiatives that Europeans propagandised as evidence of the advantages of colonial rule. They were also crucial for ensuring a healthy population from which to extract labour, in ways that relied on and propelled epidemiological activity on military populations.

Historically, there is thus close correspondence between social interventions by professionals from the health and security fields, whether to improve soldiers' performance, increase workers' productivity or ensure control over the 'dangerous classes' or the government of colonies. In this regard, Howell proposed a reorientation of research on the health-security nexus. Instead of examining moments when securitisation takes place, the global health policy literature should start with the dynamics in which medical knowledge is produced and then used, together with police, actuarial and administrative practices, in apparatuses of government. Here, it is worth quoting the author at length:

[T]o speak of 'securitisation' is to mistakenly assume that there is something pure, merely, or normally political prior to security that is not permeated with relations of force. In this sense, those in IR who have asserted that 'the exception has trickled down' to the mundane sphere of politics or the law, or that security policies 'feed back' into society are identifying an important dynamic: that there is a relation between supposedly external security and 'society'[...] Violence in the domestic realm, including the strategic violence of medicine that addresses itself to the population, cannot rightly be thought of as exceptional, or as a result of national security imperatives trickling down or feeding back. Nor can these dynamics be captured by the terms 'militarisation' or 'securitisation.' Rather, it is more accurate to observe that the features that make medicine so apt a tool for working on populations in the domestic realm are also the features that make it useful in matters of national or international security (Howell 2014: 971).

In short, a critical reading of global health policies cannot be reduced to securitisation. Instead, we argue that it should consider everyday security practices and reveal the interrelations between medical sciences and other means of control. While securitisation theory does highlight the problems of emergency practices in times of pandemic, it conceals the political practices ongoing on a day-to-day basis which also impact security agenda-setting. As long as discussion of the responses to Covid-19 focuses only on investigating whether or not a securitisation process took place, critical security studies will lose sight of the variegated forms of violence ingrained in 'normal' public health services.

Lastly, when one looks at the uses of medical knowledge in colonial enterprises and control of the 'dangerous classes', it becomes difficult to sustain the argument that 'normal policies' are peaceful and that medical practices are securitised only in times of pandemic. The logics of security and social control are not external to the practice of medicine, but 
rather - as Foucault showed - are constitutive of it. The concept of securitisation, by starting from a relation of exteriority, of security as something that happens to global health from time to time, does not grasp this constitutive nature and thus has little to say about the major challenges on the health security agenda.

\section{Conclusions: The need for a diversified Health Security Agenda}

\section{As scholars of security we are ultimately part of, and have responsibility for, the phenomena we try to understand (Elbe and Buckland-Merrett 2019: 141)}

Abandoning the logic of ruptures and policies of exception makes room for a research agenda that affords consistent, coherent dialogue about the convergence between health and security issues. A critical reading of securitisation encourages studies of how health policies operate from day to day, the challenges of agenda setting, of coordinating among different agencies and different countries, the impact of private sector lobbying, the dynamics of pharmaceutical industry innovation and the approval of patents. It also encourages research into how the medicalisation of security advances medical discourses into ever broader areas, creating new fears and anxieties, making peoples' everyday habits (i.e. the use of tobacco and alcohol) a security problem, and, as described by Elbe (2012), turning the body into a battlefield.

In addition to broadening the agenda, the demand for a genealogy of the security-health nexus which draws on institutional controversies, 'banal' practices and socio-technical mediations reveals that securitisation theory's focus on moments of rupture is politically innocuous. At times, the criticism mobilised against security discourses and sovereign decisions tends to caricature, because it is obliged to play by the grammar rules of a discourse of urgency and exceptionality, and end up being forced to choose between securitising and saving lives or de-securitising and salvaging freedom. This, however, is a false dilemma, a straitjacket self-imposed by opting for a binary analytical model that has proven simplistic. In other words, it is criticism that limits itself to two options: to favour a liberal perspective of heightened individualism, reflected at present in movements contesting social distancing measures and the use of face masks, or to accept the reproduction of the state of exception and 'bare life,' which is made clear by the recent writings of Agamben (2020) on the medical discourses that scare society to the point where it accepts incisive control measures ${ }^{3}$. This leaves no room for nuances, for horizontal solidarity, social forces, or a politics of care. Power relations are purged of historicity and complexity. That is why critics are forced, like Agamben, to choose between alarmism and underestimating the pandemic.

On the contrary, as suggested here, exploring the bureaucratic disputes and scientific controversies that constitute health security knowledges and practices enables critical approaches to engage with the multiple - and, at times, mundane - processes in which (in) security is produced, circulated and contested. Rather than analysing sovereign power and 
a securitised order, the proposal here is to observe variegated modes of ordering and the everyday (re)production of power relations. After all, as summed up by Koopman (2017),

[o]nly in following power everywhere that it operates does freedom have a good chance of flourishing. Only by analysing power in its multiplicity [...] do we have a chance to mount a multiplicity of freedoms that would counter all the different ways in which power comes to define the limits of who we can be.

\section{Notes}

1 Note that the analytical framework of securitisation has become a preferred perspective not only for those coming from security studies to analyse the security-health nexus. The vocabulary it introduced recurs in journals on social medicine, epidemiology, and public health (Elbe 2006; Delaet 2015; Wenham and Farias 2019).

2 Buzan, Wæver and de Wilde (1998: 72) - writing before the recent process intended to disqualify scientific discourse and the rise of social movements questioning knowledge production in universities and ultimately the authority of 'experts' - argued that scientists have an ability to construct notions of threat that is unlikely to be contested by politicians and society at large. Debating specifically the urgency of an environmental security agenda, they declared that ' $\mathrm{i}] \mathrm{f}$ a politician or a civilian is told by a specialist or a group of respected scientists that the oceans are overfished, the hole in the ozone layer will cause widespread skin cancer, and population growth is exceeding the carrying capacity of the earth, he or she has no reason to question this report (apart from general healthy skepticism). [...] The general public can do no more than trust or mistrust the professionals and make its political choices on that intuitive basis.' On the scientific discourse and the construction of threats in securitisation processes, see Villumsen Berling (2011).

3 This Italian philosopher has published series of papers denouncing the 'frantic, irrational, and absolutely unwarranted emergency measures adopted for a supposed epidemic of coronavirus' (Agamben 2020). His position was promptly criticised by those who endeavour to see social distancing in times of pandemic not as a policy of exclusion and the seed of neoliberal authoritarianism, but an act of mutual care and solidarity, which strengthens horizontal mechanisms of solidarity. In this regard, as noted by Panagiotis Sotiris (2020), the concept of bare life is closer to the pensioner on a waiting list for a respirator or an ICU bed, because of a collapsed health system, than the intellectual having to do with the practicalities of quarantine measures.' On Agamben's position and the bruising criticisms thereof, see Frateschi (2020).

\section{References}

Adhanom, T. 2020. 'WHO Director-General's Opening Remarks at the Media Briefing on COVID-19.' WHO, 18 March. At https:/www.who.int/dg/speeches/detail/who-director-general-sopening-remarks-at-the-media-briefing-on-covid-19---18-march-2020 [Accessed on 23 July 2020].

Agamben, G. 2020. 'The State of Exception Provoked by an Unmotivated Emergency'. Positions Politics [online]. At: http://positionswebsite.org/giorgio-agamben-the-state-of-exception-provoked-by-an-unmotivated-emergency/ [Accessed on 23 July 2020].

Al-Sharafat, S. 2020. 'Securitization of the Coronavirus Crisis in Jordan: Successes and Limitations.' The Washington Institute, 11 May [online]. At: https://www.washingtoninstitute.org/fikraforum/ view/COVID-19-Jordan-Middle-East-Securitization [Accessed on 23 July 2020]. 
Amoore, L and M de Goede. 2008. 'Transactions After 9/11: The Banal Face of the Preemptive Strike.' Transactions of the Institute of British Geographers 33 (2): 173-185.

Aradau, C. 2010. 'Security that Matters: Critical Infrastructure and Objects of Protection.' Security Dialogue 41 (5): 491-514.

2018. 'From Securitization Theory to Critical Approaches to (In)Security'. European Journal of International Security 3 (3): 300-305.

Aradau, C and R van Munster. 2009. 'Exceptionalism and the 'War on Terror': Criminology Meets International Relations.' The British Journal of Criminology 49 (5): 686-701.

Baele, S. 2020. 'On the Securitization of COVID-19'. Pandemipolitics, 9 April. At: https://pandemipolitics.net/baele/ [Accessed on 16 October 2020].

Balzacq, T. 2005. 'The Three Faces of Securitization: Political Agency, Audience and Context.' European Journal of International Relations 11(2): 171-203.

BBC [online] (2020). 'Trump Says Coronavirus Worse 'Attack' than Pearl Harbor.' 7 May. At: https:// www.bbc.com/news/world-us-canada-52568405 [Accessed on 23 July 2020].

Benton, A. 2017. 'Whose Security? Militarization and Securitization During West Africa's Ebola Outbreak.' In M Hoffman and A Su (eds), The Politics of Fear: Médecins Sans Frontières and the West African Ebola Epidemic. New York: Oxford University Press, pp. 25-50.

Bigo, D. 2002. 'Security and Immigration: Toward a Critique of the Governmentality of Unease.' Alternatives 27 (1, Suppl.): 63-92.

Bilgin, P. 2010. 'The 'Western-centrism' of Security Studies: 'Blind Spot' or Constitutive Practice?' Security Dialogue 41 (6): 615-622.

Booth, K. 1991. 'Security and Emancipation.' Review of International Studies 17 (4): 313-326.

Bradley, J. 2020. 'In Scramble for Coronavirus Supplies, Rich Countries Push Poor Aside.' The New York Times [online], 9 April. At: https://www.nytimes.com/2020/04/09/world/coronavirus-equipment-rich-poor.html [Accessed on 23 July 2020].

Buzan, B, O Wæver and J de Wilde. 1998. Security: A New Framework for Analysis. Boulder: Lynne Rienner.

C.A.S.E. Collective. 2006. 'Critical Approaches to Security in Europe: A Networked Manifesto.' Security Dialogue 37 (4): 443-487.

Caetano, G F. 2020. 'Não estamos em Guerra! A Retórica Belicista no Enfrentamento ao COVID-19'. Boletim Cientistas Sociais No. 61 [online]. At: http://anpocs.org/index.php/publicacoes-sp-2056165036/boletim-cientistas-sociais/2387-boletim-n-61-cientistas-sociais-e-o-coronavirus [Accessed on 23 July 2020].

Carmo, E, G Penna and W Oliveira. 2008. 'Emergências de Saúde Pública: Conceito, Caracterização, Preparação e Resposta.' Estudos Avançados 22 (64): 19-32.

Caso, F. 2020. 'Are We at War? The Rhetoric of War in the Coronavirus Pandemic.' The Disorder of Things [online], 10 April. At: https://thedisorderofthings.com/2020/04/10/are-we-at-war-the-rhetoric-of-war-in-the-coronavirus-pandemic/\#more-17670 [Accessed on 23 July 2020].

Chadwick, L. 2020. 'Medical Supply Shortage Spurs Global Scramble for Materials.' Euronews [online], 5 April. At: https://www.euronews.com/2020/04/04/medical-supply-shortage-spurs-global-scramble-for-materials [Accessed on 23 July 2020]. 
Chalhoub, S. 1996. Cidade Febril: Cortiços e Epidemias na Corte Imperial. São Paulo: Companhia das Letras.

Corrêa Filho, H. 2020. "Lei do CoronaVirus 2019': Autoritarismo Sem Garantias de Cidadania.' Cebes [online], 2 February. At: http://cebes.org.br/2020/02/comentario-a-lei-do-coronavirus-2019-uma-lei-autoritaria-sem-garantias-de-cidadania/ [Accessed on 23 July 2020].

Curley, M. 2011. 'The Securitisation of Avian Influenza: International Discourses and Domestic Politics in Asia.' Review of International Studies 37 (1): 141-166.

D’Arcangelis, G. 2017. 'Reframing the 'Securitization of Public Health': A Critical Race Perspective on Post-9/11 Bioterrorism Preparedness in the US.' Critical Public Health 27 (2): 275-284.

DeLaet, D. 2015. 'Whose Interests is the Securitization of Health Serving?' In S Rushton and J Youde (eds), The Routledge Handbook of Health Security. London and New York: Routledge, pp. 339-348.

Diez, T. 2020. 'Learning from Corona: Climate Change, Security and Justice.' Globus [online], 13 May. At: https://www.globus.uio.no/resources/global-justice-blog/covid-19-series/diez-corona-climate-change-may20.html [Accessed on 23 July 2020].

Elbe, S. 2006. 'Should HIV/AIDS Be Securitized? The Ethical Dilemmas of Linking HIV/AIDS and Security’' International Studies Quarterly 50 (1): 119-144.

2010a. 'Haggling over Viruses: The Downside Risk Securitizing Infectious Diseases.' Health Policy and Planning 25 (6): 476-485.

. 2010b. Security and Global Health. Cambridge: Polity.

. 2011. 'Should Health Professionals Play the Global Health Security Card?' Perspectives 378 (9787): 220-221.

. 2012. 'Bodies as Battlefields: Toward the Medicalization of Insecurity'. International Political Sociology 6 (3): 320-322.

Elbe, S and G Buckland-Merrett. 2019. 'Entangled Security: Science, Co-Production, and Intra-Active Insecurity'. European Journal of International Security 4 (2): 123-141.

Erlanger, S. 2020. 'Macron Declares France 'At War' With Virus, as E.U. Proposes 30-Day Travel Ban.' NY Times [online], 16 March. At: https://www.nytimes.com/2020/03/16/world/europe/coronavirus-france-macron-travel-ban.html [Accessed on 23 July 2020].

Eves, L and J Thedham. 2020. 'Applying Securitization's Second Generation to COVID-19.' E-IR [online], 14 May. At: https://www.e-ir.info/2020/05/14/applying-securitizations-second-generation-to-covid-19/ [Accessed on 23 July 2020].

Ferguson, N M, D Laydon, G Nedjati-Gilani, N Imai, K Ainslie, M Baguelin, S Bhatia, A Boonyasiri, Z Cucunubá, G Cuomo-Dannenburg, A Dighe, I Dorigatti, H Fu, K Gaythorpe, W Green, A Hamlet, W Hinsley, L C Okell, S van Elsland, H Thompson, R Verity, E Volz, H Wang, Y Wang, P GT Walker, C Walters, P Winskill, C Whittaker, C A Donnelly, S Riley and A C Ghani. 2020. 'Report 9: Impact of Non-Pharmaceutical Interventions (NPIs) to Reduce COVID-19 Mortality and Healthcare Demand.' Imperial College COVID-19 Response Team [online], 16 March. At: https:// www.imperial.ac.uk/media/imperial-college/medicine/sph/ide/gida-fellowships/Imperial-College-COVID19-NPI-modelling-16-03-2020.pdf [Accessed on 23 July 2020].

Fidler, D. 2007. 'A Pathology of Public Health Securitism: Approaching Pandemics as Security Threats.' In A.F. Cooper, J.J. Kirton and T. Schrecker (eds), Governing Global Health: Challenge, Response, Innovation. Aldershot: Ashgate, pp. 41-64. 
Foucault, M. 1974 [2019]. 'O Nascimento da Medicina Social.' In M Foucault. 2019. Microfísica do Poder. $10^{\text {th }}$ edition. Rio de Janeiro: Paz and Terra, pp. 143-170.

Frateschi, Y. 2020. 'Agamben sendo Agamben: O Filósofo e a Invenção da Pandemia.' Blog da Boitempo [online], 12 May. At: https://blogdaboitempo.com.br/2020/05/12/agamben-sendo-agamben-o-filosofo-e-a-invencao-da-pandemia/ [Accessed on 23 July 2020].

Goldenfein, J, B Green and S Viljoen. 2020. 'Privacy Versus Health Is a False Trade-Off.' Jacobin [online]. https://jacobinmag.com/2020/04/privacy-health-surveillance-coronavirus-pandemic-technology [Accessed on 23 July 2020].

Guillaume, X. 2018. 'How to Do Things with Silence: Rethinking the Centrality of Speech to the Securitization Framework.' Security Dialogue 49 (6): 476-492.

Guillaume, X and J Huysmans. 2019. 'The Concept of 'the Everyday': Ephemeral Politics and the Abundance of Life.' Cooperation and Conflict 54 (2): 278-296.

Guterres, A. 2020. 'Remarks to the Security Council on the COVID-19 Pandemic.' UNSG [online], 9 April. At: https://www.un.org/sg/en/content/sg/speeches/2020-04-09/remarks-security-council-covid-19-pandemic [Accessed on 23 July 2020].

Hanrieder, T and C Kreuder-Sonnen. 2014. 'WHO Decides on Exception? Securitization and Emergency Governance in Global Health'. Security Dialogue 45 (4): 331-348.

Hansen, L. 2000. 'The Little Mermaid's Silent Security Dilemma and the Absence of Gender in the Copenhagen School.' Millennium 29 (2): 285-307.

2011. 'The Politics of Securitization and the Muhammad Cartoon Crisis: A post-Structuralist Perspective.' Security Dialogue 42 (4-5): 357-369.

Harvey, D. 2020. 'Anti-Capitalist Politics in the Time of COVID-19'. Jacobin [online]. https://jacobinmag.com/2020/03/david-harvey-coronavirus-political-economy-disruptions? [Accessed on 23 July 2020].

Honigsbaum, M. 2017. 'Between Securitisation and Neglect: Managing Ebola at the Borders of Global Health.' Medical History 61(2): 270-294.

Howell, A. 2014. 'The Global Politics of Medicine: Beyond Global Health, against Securitisation Theory' Review of International Studies 40 (5): 961-987.

2018. 'Forget 'Militarization': Race, Disability and the 'Martial Politics' of the Police and of the University'. International Feminist Journal of Politics 20 (2): 117-136.

Huysmans, J. 2006. The Politics of Insecurity: Fear, Migration and Asylum in the EU. London: Routledge.

2008. 'The Jargon of Exception: On Schmitt, Agamben and the Absence of Political Society' International Political Sociology 2(2): 165-183.

2011. 'What's in an Act? On Security Speech Acts and Little Security Nothings.' Security Dialogue 42 (4-5): 371-383.

Ibrahim, T. 2020. 'Opinion: Non-Military and the Limits of National Security.' E-IR [online] 18 May. At: https://www.e-ir.info/2020/05/18/opinion-non-military-threats-and-the-limits-of-national-security/ [Accessed on 23 July 2020].

Kamdar, D. 2020. 'Global Contest for Medical Equipment Amidst the COVID19 Pandemic.' Observer Research Foundation [online] 20 May. At: https://www.orfonline.org/expert-speak/global-contest-for-medical-equipment-amidst-the-covid19-pandemic-66438/ [Accessed 23 July 2020]. 
Kamradt-Scott, A. 2015. Managing Global Health Security: The World Health Organization and Disease Outbreak Control. London: Palgrave Macmillan.

Katz, R and E Sorrell. 2015. 'Preparedness and Resilience in Public Health Emergencies.' In S. Rushton and J. Youde (eds), The Routledge Handbook of Health Security. London and New York: Routledge, pp. 201-214.

Klein, N. 2020. 'Coronavirus Capitalism: Naomi Klein's Case for Transformative Change Amid Coronavirus Pandemic.' Democracy Now [online]. At: https://www.democracynow.org/2020/3/19/ naomi_klein_coronavirus_capitalism [Accessed on 23 July 2020].

Koopman, C. 2017. 'The Power Thinker' Aeon [online], 17 March. At: https://aeon.co/essays/whyfoucaults-work-on-power-is-more-important-than-ever [Accessed on 23 July 2020].

Krasna, J. 2020. 'Securitization and Politics in the Israeli COVID-19 Response.' Foreign Policy Research Institute [online], 13 April. At: https://www.fpri.org/article/2020/04/securitization-and-politics-in-the-israeli-covid-19-response/ [Accessed on 23 July 2020].

Kuo, L. 2020. 'Coronavirus: South Korea Declares 'War' on Outbreak as WHO Experts Arrive in Iran. The Guardian [online], 3 March. At: https://www.theguardian.com/world/2020/mar/03/coronavirus-south-korea-declares-war-on-outbreak-as-who-experts-arrive-in-iran [Accessed on 23 July 2020].

Leander, A. 2011. 'The Promises, Problems, and Potentials of a Bourdieu-Inspired Staging of International Relations.' International Political Sociology 5 (3): 294-313.

Léonard, S and K Christian. 2011. 'Reconceptualizing the Audience in Securitization Theory'. In T Balzacq (ed), Securitization Theory: How Security Problems Emerge and Dissolve. London: Routledge, pp. 56-76.

Lowen, M. 2020. 'Coronavirus: EU Could Fail over Outbreak, Warns Italy’s Giuseppe Conte.' BBC [online], 9 April. At: https://www.bbc.com/news/world-europe-52224838 [Accessed 23 Jul. 2020].

McInnes, C. 2009. 'Conflict, HIV and AIDS: A New Dynamic in Warfare?' Global Change, Peace and Security 21 (1): 99-114.

. 2015. 'The Many Meanings of Health Security'. In S Rushton and J Youde (eds), The Routledge Handbook of Health Security. London and New York: Routledge, pp. 7-17.

McInnes, C and A Roemer-Mahler. 2017. 'From Security to Risk: Reframing Global Health Threats.' International Affairs 93(6): 1313-1337.

McInnes, C and K Lee. 2006. 'Health, Security and Foreign Policy'. Review of International Studies 32 (1): 5-23.

McInnes, C and S Rushton. 2013. 'HIV/AIDS and Securitization Theory'. European Journal of International Relations 19 (1): 115-138.

Moffette, D and S Vadasaria. 2016. 'Uninhibited Violence: Race and the Securitization of Immigration.' Critical Studies on Security 4 (3): 291-305.

Morozov, E. 2020. 'The Tech 'Solutions' for Coronavirus Take the Surveillance State to the Next Level.' The Guardian [online]. At: https://www.theguardian.com/commentisfree/2020/apr/15/ tech-coronavirus-surveilance-state-digital-disrupt [Accessed on 23 July 2020].

Mukherjee, T. 2020. 'The United Nations Security Council and Securitization of COVID-19.' Observer Research Foundation [online], 4 April. At: https://www.orfonline.org/expert-speak/the-united-nations-security-council-and-securitization-of-covid-19-64079/ [Accessed on 23 July 2020]. 
Nunes, J. 2014. Security, Emancipation and the Politics of Health: A New Theoretical perspective. London: Routledge.

2020. 'A Pandemia de COVID-19: Securitização, Crise Neoliberal e a Vulnerabilização Global.' Cadernos de Saúde Pública 36 (5): 1-4.

Olesker, R. 2018. 'The Securitisation Dilemma: Legitimacy in Securitisation Studies.' Critical Studies on Security 6 (3): 312-329.

Peron, A, D Edler, L Simões-Gomes and M Nery. 2020. 'Viral Surveillance: Governing Social Isolation in São Paulo, Brazil, During the COVID-19 Pandemic.' Working Paper. At: https://papers.ssrn. com/sol3/papers.cfm?abstract_id=3596054 [Accessed on 23 July 2020].

Pfrimer, M and R Barbosa Jr. 2020. 'Brazil's War on COVID-19: Crisis, not Conflict - Doctors, not Generals.' Dialogues in Human Geography 10(2): 137-140.

Reis, S. 2020. 'Pandemia Acende Debate Sobre Securitização da Saúde.' OPEU [online], 12 April. At: https://www.opeu.org.br/2020/04/15/pandemia-acende-debate-sobre-securitizacao-da-saude/\#wpcf7-f49-o1 [Accessed on 23 July 2020].

Rushton, S and J Youde (eds). 2015. The Routledge Handbook of Health Security. London and New York: Routledge.

Sears, N. 2020. 'The Securitization of COVID-19: Three Political Dilemmas.' Global Policy Journal [online], 25 March. At: https://www.globalpolicyjournal.com/blog/25/03/2020/securitization-covid-19-three-political-dilemmas [Accessed on 23 July 2020].

Sotiris, P. 2020. 'Against Agamben: Is a Democratic Biopolitics Possible?' Critical Legal Thinking [online], 14 March. At: https://criticallegalthinking.com/2020/03/14/against-agamben-is-a-democratic-biopolitics-possible [Accessed on 23 July 2020].

Stevenson, M and M Moran. 2015. 'Health Security and the Distortion of the Global Health Agenda.' In S Rushton and J Youde (eds), The Routledge Handbook of Health Security. London and New York: Routledge, pp. 328-338.

Stivas, D and N Smith. 2020. 'Coronavirus: China's Attempts to Contain the Outbreak Has Given it New Levels of State Power.' The Conversation [online], 11 March. At: https://theconversation. $\mathrm{com} /$ coronavirus-chinas-attempts-to-contain-the-outbreak-has-given-it-new-levels-of-state-power-133285 [Accessed on 23 July 2020].

Stivas, D and K Sliwinski. 2020. 'Securitizing Coronavirus: Global Risks, Responses, and Consequences.' Global-E 13 (61). At: https://www.21global.ucsb.edu/global-e/september-2020/securitizing-coronavirus-global-risks-responses-and-consequences [Accessed on 16 October 2020].

Stritzel, H. 2011. 'Security, the translation.' Security Dialogue 42 (4-5): 343-355.

Tian, Y L. 2020. 'In 'People’s War' on Coronavirus, Chinese Propaganda Faces Pushback.' Reuters [online], 13 March. At: https://www.reuters.com/article/us-health-coronavirus-china-propaganda-a/in-peoples-war-on-coronavirus-chinese-propaganda-faces-pushback-idUSKBN2100NA [Accessed on 23 July 2020].

Ullman, R. 1983. 'Redefining Security'. International Security 8 (1): 129-153.

Ventura, D. 2016. 'From Ebola to Zika: International Emergencies and the Securitization of Global Health.' Cadernos de Saúde Pública 32 (4): 1-4.

Ventura, D, F Mussa, A Aith and D H Rached. 2020a. 'A Emergência do Novo Coronavírus e a 'Lei de Quarentena' no Brasil.' Revista Direito e Práxis, online first. 
Ventura, D, H Ribeiro, G di Giulio, P Jaime, J Nunes, C Bógus, J Antunes and E Waldman. 2020b. 'Challenges of the COVID-19 Pandemic: For a Brazilian Research Agenda in Global Health and Sustainability'. Reports in Public Health 36 (4): 1-5.

Villumsen Berling, T. 2011. 'Science and Securitization: Objectivation, the Authority of the Speaker and Mobilization of Scientific Facts.' Security Dialogue 42 (4-5): 385-397.

Vuori, J. 2008. 'Illocutionary Logic and Strands of Securitization: Applying the Theory of Securitization to the Study of Non-Democratic Political Orders.' Security Dialogue 14 (1): 65-99.

Wæver, O. 1995. 'Securitization and Desecuritization.' In R Lipschutz (ed), On Security. New York: Columbia University Press, pp. 46-86. . 2011. 'Politics, Security, Theory'. Security Dialogue 42 (4-5): 465- 482.

Walt, S M. 1991. ‘The Renaissance of Security Studies.' International Studies Quarterly 35 (2): 211-30. Watterson, C and A Kamradt-Scott. 2016. 'Fighting Flu: Securitization and the Military Role in Combating Influenza.' Armed Forces and Society 42 (1): 145-168.

Wenham, C. 2019. 'The Oversecuritization of Global Health: Changing the Terms of Debate.' International Affairs 95 (5): 1093-1110.

Wenham, C and D B Farias. 2019. 'Securitizing Zika: The Case of Brazil.' Security Dialogue 50 (5): 398-415.

Wermuth, M and J L B de Morais. 2020. 'Da Exceção Agambeniana à Constituição Planetária de Ferrajoli: Desafios Impostos pela Pandemia do Novo Coronavírus às Categorias Jurídico-Politica Tradicionais.' Revista Eletrônica do Curso de Direito 15 (1): 1-29.

WHO. 2007. The World Health Report 2007 - A Safer Future: A Global Public Health Security in the 21st Century. Geneva: World Health Organization.

Wilkinson, C. 2016. 'The Copenhagen School on Tour in Kyrgyzstan: Is Securitization Theory Useable Outside Europe?' Security Dialogue 38 (1): 5-25.

\section{Acknowledgements}

Research for this article was financed by the São Paulo Research Foundation (20/05628-1) and CAPES/Pró-Defesa (88887.368551/2019-00). 


\section{About the authors}

Daniel Edler Duarte is a FAPESP postdoctoral researcher at the Department of Sociology, University of São Paulo (USP), and was formerly a CAPES/Pró-Defesa postdoctoral researcher at the Brazilian Naval War College (EGN). He holds a PhD in Politics and International Studies from the Department of War Studies, King's College London (KCL). Before joining KCL, Daniel was Konrad Adenauer Fellow in European Studies at the Getúlio Vargas Foundation's School of Social Sciences (CPDOC/FGV). Daniel has written on security assemblages, focusing on the development and implementation of policing technologies in Brazil. His current research interests are police practices and innovations, biometric surveillance, facial recognition technologies, and predictive policing.

Marcelo M. Valença is an Assistant Professor at the Graduate Program in Maritime Studies at the Brazilian Naval War College (PPGEM/EGN). He holds a Doctorate degree in International Relations (2010) and a J.D. (2004), both from the Pontifical Catholic University of Rio de Janeiro (PUC-Rio). His research interests focus on the intersection of International Politics and International Law. Marcelo has extensively published on themes such as Critical Security Studies, Brazilian Foreign Policy, Maritime Regional Security Orders, multilateralism in world politics, and active learning in International Affairs. Contact info: marcelo.valenca@marinha.mil.br / www.marcelovalenca.com. 


\section{Securitizando a COVID- 19? A política de saúde global e os limites da Escola de Copenhagen}

Resumo: A pandemia de COVID-19 tem gerado controvérsias em torno das políticas de saúde adotadas em diferentes países. A necessidade de controlar a propagação do vírus tem sido usada como justificativa para medidas de restrição da mobilidade e para largos investimentos em dispositivos de vigilância, o que pode abrir espaço para formas não democráticas de governo. Nesse contexto, a Escola de Copenhague tem oferecido o instrumental teórico que informa muitas das análises nos campos de estudos críticos de segurança e saúde global. Segundo esta perspectiva, a securitização da COVID-19 agiliza as respostas à crise, mas guarda caráter discriminatório, contribuindo ainda para o avanço de políticas autoritárias potencialmente duradouras. Neste artigo, exploramos os debates recentes em torno das políticas de contenção da pandemia para abordar os limites políticos e analíticos da teoria da securitização. Por um lado, demonstramos que o foco em momentos de ruptura e políticas de exceção negligencia práticas de segurança que se desenvolvem no dia a dia das disputas institucionais e na construção de conhecimento especializado sobre saúde pública. Por outro, apontamos que a proposta da Escola de Copenhague impede uma genealogia dos aparatos modernos de segurança e ignora formas violentas de governo que não se manifestam em grandes atos disruptivos, mas na rotina de sociedades desiguais. Sugerimos, por fim, que a análise das disputas burocráticas e controvérsias científicas que constituem os conhecimentos e práticas dos campos de segurança e saúde permite que abordagens críticas se engajem com os múltiplos e, por vezes, mundanos processos pelos quais a (in)segurança é produzida, disseminada e contestada.

Palavras-chave: securitização; Escola de Copenhague; política cotidiana; segurança sanitária; sociologia política internacional; estudos críticos de segurança; pandemias.

Received on 08 July 2020, and approved for publication on 17 January 2021.

\section{(c)) BY-NC}

https://creativecommons.org/licenses/by-nc/4.0/ 